\title{
Halfway to 90
}

\author{
Kenneth J. Zucker ${ }^{1}$
}

Published online: 3 January 2017

(c) Springer Science+Business Media New York 2016

Archives turned 45 last year,so we are halfway to 90. I am not sure how many of the current members of the Editorial Board will still be reviewing for the Journal in another 45 years, so it is probably best to note something now.

\section{Richard Green Founding Editor Essay Award}

Beginning in 2017, the Archives of Sexual Behavior will launch the annual Richard Green Founding Editor Essay Award. It will be for an article published in Archives that is judged the best "think piece" of the year on gender and/or sexual behavior submitted to the Journal. Upon submission, the corresponding author should request, in a cover letter, that the paper be considered for this award. The winning essay will be chosen by a multidisciplinary committee of Editorial Board members. The winner will receive an award of $\$ 1000$. The International Academy of Sex Research (IASR) and the Archives thank Richard Green for his generosity, for founding the IASR, and for his 30 years as Archives Editor (1971-2001).

\section{Editorial Board}

With the start of Volume 46, I am pleased to announce that Lisa Dawn Hamilton has agreed to serve as an Associate Editor, replacing Jesse Owen, who has stepped down and moved back to the Editorial Board at large. Dr. Hamilton will handle submissions that Dr. Owen was responsible for, including papers on friends-with-benefits, (heterosexual) casual sexual relationships ("hookups"), and the emerging specialty area of non-monogamy.

I am also pleased to announce several new members of the Editorial Board: Laura Baams, Taylor Kohut, Gu Li, David Pantalone, Samuel Perry, Laura Widman, Wang Ivy Wong, and Sarah Woolf-King. Stephanie Budge and Ritch Savin-Williams have stepped down to concentrate on other important matters, such as applying for tenure and enjoying quasi-retirement.

Kenneth J. Zucker

ken.zucker@utoronto.ca

1 Department of Psychiatry, University of Toronto, Toronto, ON M5T 1R8, Canada 